\title{
Ellipsis
}

Volume 45

Article 17

2018

\section{That Look She Gives Me}

Glennis Waterman

University of New Orleans, New Orleans

Follow this and additional works at: https://scholarworks.uno.edu/ellipsis

\section{Recommended Citation}

Waterman, Glennis (2018) "That Look She Gives Me," Ellipsis: Vol. 45 , Article 17.

DOI: https://doi.org/10.46428/ejail.45.17

Available at: https://scholarworks.uno.edu/ellipsis/vol45/iss1/17

This Creative Nonfiction is brought to you for free and open access by the Department of English and Foreign Languages at ScholarWorks@UNO. It has been accepted for inclusion in Ellipsis by an authorized editor of ScholarWorks@UNO. For more information, please contact scholarworks@uno.edu. 


\section{GLENNIS WATERMAN}

\section{That Look She Gives Me}

My mother forks up a piece of cut pineapple from her plastic dish of fruit cup and holds it up to show me. "Why?" It is a plaintive little wail. "Why do they cut them so big?" she asks. "Who can put something like this in their mouth?" She looks sideways at me with a grimace of a smile. I know this expression. She is sharing her disappointment in the world with me. She is telling me that $\mathrm{I}$, of all the people in this dining room, am the only one capable of understanding her deep sense of affront at the inconsiderate people who prepared her fruit cup.

She puts the chunk of fruit on her plate and, her hands quivering slightly, cuts it into three pieces with her knife. She spears one and pops it into her mouth, chewing greedily.

Mom is 91 years old. We are having lunch in the dining room of her assisted living home. Her walker is poised right beside her chair. All around the room, at other tables, scores of walkers are poised similarly beside chairs.

A large woman wearing scrubs patterned with Hello Kitty symbols comes to the table and presents a tray of fresh-baked cookies. Her name tag reads 'Luci.'

Mom smiles. "This is my daughter Glennis," she says, indicating me. "She's having lunch with me."

"Yes, Otillie," says the woman. "I met her earlier."

Luci and I had, in fact, met just twenty minutes ago when I sat down. But, hearing her use my mother's name, I realize with a small start of surprise that, in this place, surrounded by her peers and by people dedicated to serve her, my mother's name isn't "Mom" anymore to anyone but me. To them she is Otillie, as she had been before she became my mother.

Luci and I smile at one another. "How is your soup?" she asks me.

"Great," I say.

"The food here isn't very good," says Mom, in a low aside to me. She pokes listlessly at the two small rectangular pieces of pizza on her plate. "This isn't what I'd call pizza."

"The soup was great," I say to Luci, pitching my voice a little louder. "Thank you 
so much."

No matter what it is, nothing is good enough to satisfy my mother. The cookies, it turns out, are undercooked. "I like them to be crisp," she says. "Not chewy like this."

In addition to being too large, the chunks of pineapple sometimes have part of the core attached, she complains. The soup course of Southwestern Turkey Chili is pronounced "just weird. I've never heard of chili made of turkey." The ice cream isn't very good either. She's suspicious why they decided in recent months to offer dark blue paper napkins instead of the white ones she's used to, and she disapproves of the water carafes now placed on the tables for self-service. "Some of the residents can't lift a full carafe," she says. Yet before the carafes came along, Mom criticized the wait staff for being slow to refill her glass when she needed more water.

My mother has been a widow for 16 years. Dad's winter flu turned to pneumonia and took him quickly. After he died, she stayed in the three-bedroom house they'd bought after he retired. Southerners by birth, they' $\mathrm{d}$ lived in the Northeast and upper Midwest for most of their married life, as Dad's career took him from one corporation to another. Upon retirement, they'd returned to the South, to a small college town in east Texas. Though thousands of miles away from the scattered locations where my brothers and I live, it was supposed to be the perfect retirement community - it had a top-notch medical center and the college's arts and intellectual offerings to occupy them. They didn't know anyone in town when they arrived, but Dad made friends quickly. He met the neighbors, the members of the Optimists' Club, the yardman and the clerk at the liquor store.

Mom was the shy one. When he died, her social world shrank.

And then her spatial world gradually shrank too. She did not go out unless it was necessary. Like that of a dying moon, her orbit decayed. I remember some six years after Dad's death I arrived for my annual visit. I gave her frail shoulders a hug. She hugged me back fervently and then told me that she hadn't touched another human being in over two weeks.

The first time she fell was in 2008. I knew of three falls she took - one happened while I was visiting. Recently, she confessed to me that there had been many moreperhaps nine or ten. One morning, she fell in her driveway while taking the garbage bin down to the street. She lay there until the garbage truck arrived, and the worker 
saw her and called for help.

After that one, she agreed to sell the house and move into an assisted living facility. The place we found is in the western suburbs of Chicago. It's about three miles from my brother Gordon's house, and about a mile from the office where he and his twin, my brother Barrett, work. Today, she is surrounded by family - Gordon and his wife Mary, their son, his wife and kids, two little great-grandchildren. Barrett and his family live about ten miles away.

There are four of us kids. I'm the oldest, and the only girl. Stuart is the second kid; he and his wife have lived in China for over thirty years. The twins, Gordon and Barrett, live in the Chicago area. "Are they identical?" someone at lunch asks during my visit with Mom.

She laughs. "Well," she says, "in the delivery room, the doctor said they both came out of the same paper bag!"

Gordon and Mary shoulder much of the burden of caring for Mom. Gordon visits regularly, bringing her books from the local public library. He takes care of her finances. Mary does her personal laundry, and shops for the little things she constantly demands: reading glasses, lip balm, socks, note cards and nail clippers.

I've gotten off easy. I live in a distant city. I talk to her on the phone, and I try to visit at least once a year. When I visit, I like to come around lunchtime. She enjoys showing me off to the other residents in the dining room. I like the ritual of eating, of saying hello to people. It's less oppressive than being trapped with her in her apartment.

Mom lives in two rooms; a bedroom and a small sitting room. There is a tiny kitchenette, with a dorm-room size fridge and a little sink. When we moved her here in 2008, Gordon and I bought her new furniture. She has a love-seat that can fold out to a bed, if anyone would ever want to visit her overnight. My nephew Collin drove up from Texas with the few items from the old house we kept-some end tables, some framed artwork, a pair of lamps.

Mom spends most of her days sitting in a beige recliner chair. When I walk down the halls of her building and pass other residents' open doors, I see chairs identical to hers except in color. With a touch of a button, you can elevate the footrest or boost up the seat to help a frail person stand up. The broad padded arms of the chair flip open, revealing spacious compartments that hold all the things a person might need - nail clippers, magnifying glasses, packets of facial tissues, lip balm, Tic-Tacs, pens and 
memo pads, even a little box of chocolates.

Her room is always warm and stuffy. A little clock and weather station shows the inside temperature at 81 degrees Fahrenheit. Sitting here after finishing a bland lunch with her, I feel my eyelids closing.

"I'm so bored," Mom tells me frequently. "I just sit here, day after day." Her mood has improved from her initial arrival here, when this complaint was usually supplemented by the phrase, "just waiting to die." Now she zealously guards her health, forgoing visits from her own great-grandchildren for fear she'll catch a cold. She used to enjoy a small glass of sherry before dinner, but now she worries about becoming a drunkard. She has cut back on her pain pills, enduring her aches and pains to avoid becoming a drug addict.

"There's nothing that interests me anymore." She won't participate in group activities at the facility. She doesn't care about shopping or excursions. "They take people out on a bus," she says. "But I have this walker! How will they keep track of it for me?" I used to respond to this complaint by pointing out that everyone on the bus has a walker, and that the staff has probably figured out how to keep track of them, but I've since learned Mom is immune to that kind of logic. Now I just let her talk.

Mom used to roam the halls for exercise, but in recent years she's slacked off. These days she amuses herself with crossword and sudoku puzzles, and watching the stock market report on TV. A tray table is set up to her right, stacked high with her stuff. Magazines. National Geographic: "It used to be more scientific." The New Yorker: "It's not what it once was. It's so political these days." History Today: "Did I tell you how Mary brought me this magazine? It's from England." An atlas: "I like to look up places I read about." The TV remote. Her iPad.

Yes, Mom has an iPad. She proudly shows me that she can read the New York Times on it. She's adept at finding the baseball scores, the weather report. But when I pull out my iPhone she says, "Oh, I wouldn't know how to work one of those things."

I say, "Mom, it's just like your iPad only smaller."

"Well," she says. She looks at her screen. Then she changes the subject. "Look at these things!" she says. She points at the icons of all the aps on her tablet desktop. "What are these things? Why do I need these? Why?" It is the same plaintive wail she uttered about the pineapple.

"Contacts," she snarls with scorn. "What is that, and why would anyone want 
it?"

"It's like an address book, Mom," I say.

She fumbles in the armrest compartment and pulls out a small notebook. "Well, I have an address book, I don't need another one."

Each afternoon I listen to her catalog the other items that bedevil her, that make her cry out "Why?" in her unending quest for meaning.

The width of the elastic band at the tops of her nylon ankle socks. "Why is it so narrow? It digs into my skin."

The ads that come on before the Dow Jones report on TV. "Why do they run all these ads? I just want to see the news."

The closure on the box of Tic-Tacs. "Why do they make it so small? I can barely open it." She tears at it with her thumbnail.

The activities offered for facility residents. "Movie night. Why on earth would I want to do that? I don't watch movies!"

The graphic design of a magazine. "Why is the print so small? How do they expect someone to read it?" I have to admit, at 63 now, I'm not unsympathetic to that one.

The world, it seems, is full of people who insist on making aesthetic decisions intended specifically to offend and inconvenience my mother. She gives me That Look again, the one that says, only you, my daughter, can understand how I feel about the world.

I cringe at that look. I want to say, No, Mom, I'm not you. I'll never feel the way you do about the world, about people. I want to actively reject that look, but I can't. She's my mother, after all.

Otillie was once a beautiful woman, slim and quite stylish. As a Texas farm girl married to a young corporate executive, she adapted herself; she put on airs. When we sold the East Texas house, we found a closet full of Ferragamo shoes in perfect condition. When I was a child, she was the arbiter of my aesthetic tastes. Each year before school started she'd take me shopping at the Merrilees Dress Shoppe in Geneva, Illinois, choosing color-coordinated ensembles of skirts, sweaters and shoes. She let me pore with her over swatches of upholstery and drapery fabric. She taught me about flowers, and classical music, and how to look at the marks on the bottom of fine china. During my visit, she tells me of her plans to reorganize her dresser drawers for the changing seasons. Though she has not set foot outside her building in more than two 
years, I listen patiently as she says it's time to get out her white slacks and sandals for summer. Her rarified sense of refinement, despite its snobbishness, is nevertheless her legacy to me. Though I know it's ridiculous, I can't help but have a preference for Pepperidge Farm cookies over Nabisco (like her, I like my cookies crisp!).

My mother plucks at the slack skin on her arm, then holds her hands out in front of her, looking at them. "My hands are so ugly now." Though she disparages her appearance, at 91 she is still slim, and pretty when she smiles. She fingers a snow white lock of her hair, as fine and wispy as a child's. "My hair is so thin!"

When I was in my early twenties, I wrote in my journal about the old people who ate at the restaurant where I worked.

I look at old ladies I serve dinner to and I wonder: Were you twenty, ever? You're so tiny, so frail, so slow. Were you ever alive and vigorous, fast moving. Did you ever dance all night long, did you ever have sex, did you ever run, fight, laugh, cry? How could you have-you're so frail! I wonder did your legs, that are scrawny now, purple veins ugly on the skin, your toes pointed stiffly out as you hobble - did your legs ever look like mine? I look at my hand and wonder how it could ever be like hers - pale, so pale as to be transparent you can see the blue veins and the pale knobs of bone, the swollen joints, thin, tiny, strengthless hand. I look at my arms - round, smooth, tanned golden, muscles swelling beneath the moist supple skin-and I don't understand how it will ever be pale, scrawny, the muscles dissolved to nothing, a little dry meat hanging to the bones, like a chicken wing; the skin white and age-spotted, hanging loose, with a texture like crepe. I don't understand how these things could possibly happen I just know it will. And I wonder how it would feel.

Reading that now I am ashamed at the arrogance of my young self. Now, I sure do know how it feels, looking at my own veined hands and the crows feet around my eyes. I see how my skin, like Otillie's, is getting thinner. Yet at the same time, I pray I am not like her. Her snobbishness. Her detachment. Her negativity. Her lack of charity and empathy. Her disdain for how other people live their lives. "Why would anyone want to do that?" she asks, whether it's a college major, a breakfast selection, or a fashion choice. Her mind-set seems as alien to me as if she were another species.

In the dining room, my mother introduces me to her table-mates. She has always had a hard time making friends but here, she is forced to spend her mealtimes in the company of others. There's Ann, whose cheerfulness is unhampered, despite an unfortunate cancerous growth around her mouth. There's Betty, a newcomer who tends to ask too many personal questions. And there's absent-minded Jane, who sometimes 
loses track of her spoon. Mom is cordial but she doesn't really converse. I try to make conversation, asking polite questions: How was their holiday? Have they had visitors? Are they rooting for the Cubs this season? Mom listens impatiently and then interjects, "This cookie is as hard as a brick."

In the privacy of her room, Mom doesn't hold back from trashing those very same neighbors. It's oddly depersonalized, as though she were speaking of strangers in a public park. "Some of these people here are weird," she tells me.

"How so?" I ask.

“There's a gal at my table who, every day, always orders exactly the same thing at breakfast," she says.

And I'll realize that she's speaking of Ann, or Betty, or Jane-people we've just spent lunchtime chatting with. Often Mom uses these observations as a means to champion her own sensible and non-weird behavior. "Every day, it's cornflakes cornflakes cornflakes. Yeesh! Not me," she proclaims. "I like variety!"

What's behind this odd depersonalization of her peers, her reduction of them to "real characters," as she calls them? Over the ten years she's lived here, she has watched her table-mates decline and disappear, as dementia and ill health takes its inexorable toll. "She stopped coming to the dining room," she'll say, "and then she just wasn't here anymore." Fear briefly clouds her eyes like a haze, then clears, willed away.

On her way back from lunch, thumping her walker firmly as she goes, she might point out one resident or another as we pass open doors. "That one is just strange. She always chews with her mouth open. I don't know if she's aware she does it, but it's just awful. I can't imagine sitting next to her at dinner."

Mom thinks facility staff should shield her from the unpleasant weirdness of people like this. "A man comes in once a month to give piano recitals. He's really very good. But there's this one woman who sits there making a noise through the whole thing. 'Glumph, glumph.' Who wants to listen to that? You'd think the people who work here would keep her away from these kind of activities," she says. "Why ruin it for everybody?"

I think complaining about the food while at the table might be ruining lunch for other diners, but instead I ask, somewhat rhetorically, "But she must enjoy hearing the music. Is a little noise really ruining it, Mom?"

She cuts me off with a steely look. "Yes. Yes it is." On her face, the fear is replaced by firm conviction. "They should do something about it." 
I feel guilty that I allow her to annoy me. And I think of all the times she must have tolerated my behavior as a child. There is a photo of her, taken when I was around five. My three-year-old brother Stuart and I are playing in a sandbox. Otillie is sitting on a lawn chair, wearing a white cotton top and striped shorts. She is young, and pretty, but clearly quite bored. She's slumped into the chair, her fine legs curled beneath her, her feet in ballet flats toed-in gracelessly. Her elbow is on the armrest, and she rests her chin in her hand.

I try to remember what she used to do all day when we were kids. She read, she played the piano. She had her hobbies - quilting, genealogy. She gardened. They were things she could do by herself. When cleaning out the east Texas house, which had somehow managed to accumulate every possession my parents owned throughout their married lives, I found a Japanese calligraphy set, complete with paper, brushes, quills and dried up bottles of ink, hidden away in a closet. I never ever saw her use it. When the last of us kids went away to college, Dad told her she needed to get out of her shell. He urged her to get a job. She looked in the want ads and ended up working for fifteen years for the State of New Jersey Human Services department. The generous pension she earned from that job now pays her rent and expenses here in the facility.

In literature, there are plenty of troubled relationships between mothers and daughters. Manipulative mothers. Cruel mothers. Vicious mothers. Mothers who hold their daughters to ridiculous standards of body image, who poison a daughter's feelings of self-esteem and femininity. Mothers who meddle in their daughter's life choices. My mother has never been that way to me. Although she sometimes cautions me about worldly hazards and pitfalls that she is wildly out of touch with (internet dangers, sex, and workplace politics), she never criticizes me; and never meddles with my life.

On the contrary, there is an air of detachment about her. She shrinks from emotional closeness, which makes her appear dismissive or lose interest, even at her most vulnerable. When Dad was dying, she could not bring herself to stay at his ICU bedside more than five minutes. She'd linger, clutching her purse before her, and I could see the fear overcome her before she'd dart from the room. I was sad but not angry. I understood. Sometimes we cannot bear the sight of another person's pain, because it is too close to our own.

More recently, the news of my divorce, though it spurred a heartfelt blurted cry 
of "Oh no!" brought no inquiry as to why. She also never asked me how I would be getting on financially. Perhaps I should be flattered she trusts I'm competent enough to take care of myself.

She has managed to reshape the narrative of her life in order to omit unhappiness or trouble. As we sit in her apartment after lunch, she points out a bud vase on the TV cabinet. "When I arrived here at this place, I brought that vase along with a beautiful rose in it. Chicago Peace. My next-door neighbor Danny in Texas cut a bloom and gave to me, just before I left. I took it in the car, and it opened from bud to full bloom on the drive up." She tells me this story, without a sign or hint of acknowledgement of the fact that I had accompanied her on that trip in 2008. Actually, Danny had handed the cut rosebud to me. My brother Gordon and I had driven her from Texas to Illinois in his Audi wagon. She had been so weak we'd actually feared for her life. We'd made her a nest of blankets and pillows in the backseat, like a couch for a dowager queen. We'd catered to her every need and food preference. Multiple times, I'd had to heave her body up off toilet seats in roadside restaurant bathrooms, her legs too feeble to rise on her own. We sought out ADA-compliant motel rooms in small towns, and then once she fell asleep, Gordon and I would sneak out to the bar, as though we'd just put a child to bed. We plied her with bottled water, pod-casts, Kleenex, and crossword puzzles to occupy her time. Her story omits the fear and urgency of that five-day trip. Gordon and I had taken off work, left our families behind, and tapped out our credit cards. What she remembers now is Danny's rose, which, indeed, had travelled up to Illinois in a bud vase wired to the Audi's dashboard. Gordon and I are no longer in her story.

Back in 2007 I started a personal blog, in response to my mother's refusal to travel. I wanted to give her a virtual look at my life in Los Angeles. She enjoyed it reading it on her iPad. But after ten years and some significant life changes, I've sort of burned out on posting.

My brother Gordon, in what is one of the mildest rebukes a person can give his sibling, said to me, "She's always checking your blog. But it looks like you haven't updated it since October."

I apologize, feeling guilty.

"Maybe you could just drop her an email every once in a while," he says. "With some photos or something. She always checks that, too."

I vow to do better. 
I'm not the only one who neglects her. She says she hasn't heard from Stuart in several months. He lives in China and has health problems, which may explain that. More puzzling, my brother Barrett, who lives just ten miles away, has not visited Mom since last March. I ask Gordon what's up. He and Barrett work in the same building. He shrugs. "On Fridays when I leave the office, I tell him I'm going to see Mom and ask him if he wants to join me. He never does."

What happened? Some encounter between Mom and Barrett must have made him draw the line. Maybe her relentless negativity, her complaints just overwhelmed him. But how? How could she have touched him so deeply when she can barely scratch the surface with me? I don't know. Perhaps, like Mom, he could not bear the closeness of another person's unhappiness.

I look at the photo of Otillie in the lawn chair again. She is looking to the side, away from the camera. Other than the darkness of her hair in the photo, she looks the same way she does today - her mouth a little sour, bored. Lost in thought. Does she possess an inner life that no one else can see? Is there someone beyond the camera frame she seeks out, as though to say, only you can understand my feelings.

Back in her room after lunch, Mom shows me how she can do the New York Times crossword on her tablet. She reads me a clue: "It says 'Comes with the territory.' What is that? Twenty four across - oh, it's one of those lo-o-o-ng answers. These new puzzles. They're not the way crossword puzzles are supposed to be. It just irritates me! Why?" She sighs. And gives me That Look again.

That Look begs for a response. A confirmation. An assent, to share in her disappointment at life's betrayal. To affirm, if I can, an answer to her existential plea for meaning in a changing world.

I shrug, and my eyes break the connection with hers. I can't give her that, or be that person for her. I gaze past her to look out her window at the afternoon light in the parking lot, glinting off the shininess of my rental car. She has taken her afternoon pain pill, and will be napping soon. "Well, Mom, I better head out. I'm meeting Gordon and Mary later."

"Well. It's been so good to see you."

In spite of my rejection, she loves me. I will never doubt that. She pushes her walker away from her chair and rises to embrace me. Her shoulders are so frail but she 
grips me tight, quivering with emotion. "My favorite daughter!" she says, jokingly. I laugh. "I'm your only daughter, Mom!" 